\title{
Case study of the diurnal variability of chemically active species with respect to boundary layer dynamics during DOMINO
}

\author{
B. J. H. van Stratum ${ }^{1}$, J. Vilà-Guerau de Arellano ${ }^{1}$, H. G. Ouwersloot ${ }^{1,2}$, K. van den Dries ${ }^{1}$, T. W. van Laar ${ }^{1}$, \\ M. Martinez ${ }^{2}$, J. Lelieveld ${ }^{2}$, J.-M. Diesch ${ }^{3}$, F. Drewnick ${ }^{3}$, H. Fischer ${ }^{2}$, Z. Hosaynali Beygi ${ }^{2}$, H. Harder ${ }^{2}$, E. Regelin ${ }^{2}$, \\ V. Sinha ${ }^{4}$, J. A. Adame ${ }^{5}$, M. Sörgel ${ }^{6, *}$, R. Sander ${ }^{2}$, H. Bozem ${ }^{2}$, W. Song ${ }^{2}$, J. Williams ${ }^{2}$, and N. Yassaa ${ }^{2,7}$ \\ ${ }^{1}$ Wageningen University, Meteorology and Air Quality Section, Wageningen, The Netherlands \\ ${ }^{2}$ Max Planck Institute for Chemistry, Department of Atmospheric Chemistry, Mainz, Germany \\ ${ }^{3}$ Max Planck Institute for Chemistry, Particle Chemistry Department, Mainz, Germany \\ ${ }^{4}$ Indian Institute of Science Education and Research Mohali, Sector 81, S. A. S. Nagar, Manauli PO, Punjab, 140306, India \\ ${ }^{5}$ National Institute for Aerospace Technology, Atmospheric Sounding Station - El Arenosillo, Mazagón, Spain \\ ${ }^{6}$ University of Bayreuth, Atmospheric Chemistry Research Laboratory, Bayreuth, Germany \\ ${ }^{7}$ University of Sciences and Technology Houari Boumediene, Faculty of Chemistry, Algiers, Algeria \\ * now at: University of Bayreuth, Junior Professorship in Atmospheric Chemistry, Bayreuth, Germany
}

Correspondence to: J. Vilà-Guerau de Arellano (jordi.vila@wur.nl)

Received: 13 February 2012 - Published in Atmos. Chem. Phys. Discuss.: 1 March 2012

Revised: 12 May 2012 - Accepted: 27 May 2012 - Published: 19 June 2012

\begin{abstract}
We study the interactions between atmospheric boundary layer (ABL) dynamics and atmospheric chemistry using a mixed-layer model coupled to chemical reaction schemes. Guided by both atmospheric and chemical measurements obtained during the DOMINO (Diel Oxidant Mechanisms in relation to Nitrogen Oxides) campaign (2008), numerical experiments are performed to study the role of ABL dynamics and the accuracy of chemical schemes with different complexity: the Model for Ozone and Related chemical Tracers, version 4 (MOZART-4) and a reduced mechanism of this chemical system. Both schemes produce satisfactory results, indicating that the reduced scheme is capable of reproducing the $\mathrm{O}_{3}-\mathrm{NO}_{\mathrm{x}}-\mathrm{VOC}-\mathrm{HO}_{\mathrm{x}}$ diurnal cycle during conditions characterized by a low $\mathrm{NO}_{\mathrm{x}}$ regime and small $\mathrm{O}_{3}$ tendencies (less than $1 \mathrm{ppb}$ per hour). By focusing on the budget equations of chemical species in the mixedlayer model, we show that for species like $\mathrm{O}_{3}, \mathrm{NO}$ and $\mathrm{NO}_{2}$, the influence of entrainment and boundary layer growth is of the same order as chemical production/loss. This indicates that an accurate representation of $\mathrm{ABL}$ processes is crucial in understanding the diel cycle of chemical species. By comparing the time scales of chemical reactive species with the mixing time scale of turbulence, we propose a classification based on the Damköhler number to further deter-
\end{abstract}

mine the importance of dynamics on chemistry during field campaigns. Our findings advocate an integrated approach, simultaneously solving the ABL dynamics and chemical reactions, in order to obtain a better understanding of chemical pathways and processes and the interpretation of the results obtained during measurement campaigns.

\section{Introduction}

Present day research on atmospheric chemistry covers a vast range of scales and approaches. Focusing on isoprene, there are for instance highly fundamental studies, either based on a theoretical approach (Peeters et al., 2009) or on small scale laboratory experiments in reaction chambers (Paulot et al., 2009), and studies with a more applied approach. Examples of the latter are controlled experiments in box models (Sander et al., 2011) and simulations at a global scale using global transport models (Stavrakou et al., 2010). However, in order to obtain a better understanding of the chemical system in real-life conditions, field experiments like e.g. TROFEE (Tropical Forest and Fire Emissions Experiment, Yokelson et al., 2007), DOMINO (Diel Oxidant Mechanisms in relation to Nitrogen Oxides, Sörgel et al., 2011; Crowley et al.,

Published by Copernicus Publications on behalf of the European Geosciences Union. 
2011; Diesch et al., 2012; Sinha et al., 2012) and HUMPPACOPEC (Hyytiälä United Measurement of Photochemistry and Particles - Comprehensive Organic Particle and Environmental Chemistry, Williams et al., 2011) are conducted, the majority of which are strongly modulated by the diurnal variability of the atmospheric boundary layer (ABL). This adds further complexity to the interpretation of the data, which is often undervalued. Here, in analyzing this variability of the reactants during DOMINO, we propose an integrated approach, simultaneously solving the ABL development and chemical transformation within a conceptual meteorological model in order to obtain a better understanding and representation of the daily cycle of chemical species.

The temporal and spatial distribution of chemical reactive species is driven by chemical and dynamical processes. Previous research has quantified that under convective diurnal conditions characterized by a strong diel cycle (similar to the current case study), the influence of boundary layer growth and entrainment can be of similar order of magnitude to the emission and deposition processes (Martin et al., 1988; Ganzeveld et al., 2008; Vilà-Guerau de Arellano et al., 2011). ABL dynamics acts on similar time-scales (ranging from 10$50 \mathrm{~min}$ ) as certain chemical transformations, and in consequence the dynamics and chemistry have to be addressed as an integrated system (Vilá-Guerau de Arellano et al., 2004). The effect of dynamics on chemistry has been also investigated on the flux of chemical species and its reactivity. We selected two studies because of its representativeness and connections to our work. First, for a similar $\mathrm{O}_{3}-\mathrm{NO}_{\mathrm{x}}-\mathrm{VOC}-\mathrm{HO}_{\mathrm{x}}$ system as studied here, Gao et al. (1993) showed large deviations from the expected linear profile due to the species reactivity, that has a direct influence on the deposition of the reactive. For the same chemical system and ABL conditions, Ouwersloot et al. (2011) analyzed in depth the main processes driving the reduction of the reactivity, like surface heterogeneity of emission and buoyancy, and wind direction. Their findings show that the reactivity can be slowed down between 10-20\%, depending on the conditions.

Here, we extend on these previous investigations by closely analyzing a complete set of diurnal observations of chemistry and meteorology. Therefore, the novelty of the study is to have for the first time a complete set of chemical and meteorological observations to guide our modeling experiments and further validate our findings. We systematically study the effect of boundary layer dynamics on atmospheric chemistry by quantifying their respective influence by means of a mixed-layer model coupled to a chemical reaction scheme. Under diurnal conditions, mixed-layer theory is a satisfactory compromise between a box model (no characterization of ABL dynamics) and more advanced 3-D (largeeddy simulation, mesoscale or global circulation) models. The conceptuality of the mixed-layer model enables us to obtain insight on the underlying processes and is very suitable/complementary for the interpretation of measurement data. More specifically, we use one representative day during the DOMINO measurement campaign, conducted in November 2008 near Mazagón, south western Spain. The campaign focused on the diel cycle of chemistry in relation to meteorology, combining the measurement of chemical species with meteorological surface and upper air observations. With (amongst others) ozone, nitrogen oxides and vertical profiles of temperature and moisture, the dataset provides a unique opportunity to comprehensively study and validate the interplay between dynamics and atmospheric chemistry in the ABL.

Using the measurement data, we reproduce the boundary layer development of a single day during DOMINO with the mixed-layer model. Two different reaction schemes are integrated in the mixed-layer model: the Model for Ozone and Related chemical Tracers, version 4 (MOZART-4, hereafter: MOZART) (Emmons et al., 2010) and an extended version of the reaction schemes used by Vilà-Guerau de Arellano et al. $(2009,2011)$ and Ouwersloot et al. (2011). The latter consists of a reduced mechanism of the chemical system. In absence of a complete set of measurements, this minimizes the assumptions made in the initial and boundary conditions, like the initial mixing ratios or surface emissions or deposition.

Our main objectives are: (1) to quantify the influence of boundary layer dynamics on atmospheric chemistry by analyzing the specific contribution of the main processes under convective conditions, (2) to show the benefits in using conceptual models as a method to obtain a better understanding and complementary information of measured data and (3) to discuss the current state of the art of modeling, comparing the complex MOZART chemical scheme with a simplified reaction scheme.

Our research approach and structure of the article is as follows: Sect. 2 describes the mixed-layer model and chemical reaction schemes. In Sect. 3 the large scale atmospheric synoptic and boundary layer dynamics of the studied day are addressed, followed by the design of the numerical experiments. In Sect. 4 we discuss the modeled results, comparing MOZART and the reduced scheme with measurements. Next, we examine the budget equations of chemical species, separating the influence of boundary layer dynamics (entrainment and boundary layer growth) from the contributions of other processes like surface emission/deposition or chemical transformations. This allows us to study the relative importance of boundary layer dynamics compared to chemical reactions. This is further supported by studying the characteristic time scales of chemistry and turbulence as an appropriate indicator of the relevance of chemistry versus dynamics for fast and slow reacting chemical species. In Sect. 5 we conclude the paper by summarizing the main conclusions. 


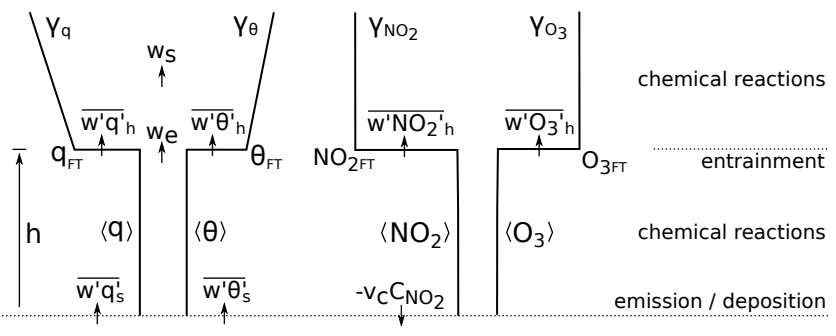

Fig. 1. Conceptual representation of the vertical profiles of specific humidity $(q)$, potential temperature $(\theta)$ and, as an example, nitrogen dioxide $\left(\mathrm{NO}_{2}\right)$ and ozone $\left(\mathrm{O}_{3}\right)$. Within the mixed-layer all variables are constant with height (Eq. 1), topped by an inversion defined as $\Delta \phi=\phi_{\mathrm{FT}}-\langle\phi\rangle$ (Eq. 3). The processes that are relevant for chemistry are shown on the right side, with emissions and deposition near the surface, chemical reactions within the mixed-layer and free-troposphere, and entrainment of free-tropospheric air at the mixed-layer top $\left(\overline{w^{\prime} \phi^{\prime}}\right.$ h, Eq. 2).

\section{Mixed-layer model}

\subsection{Representation of boundary layer dynamics}

The MiXed Layer CHemistry model stems from the pioneering research of Lilly (1968); Betts (1973); Tennekes and Driedonks (1981) on the dynamics of clear and cloudy boundary layers. In short, the model solves the time development of idealized vertical profiles of dynamic variables (potential temperature $(\theta)$, specific humidity $(q)$ ) and chemical species $(S)$ like nitrogen dioxide $\left(\mathrm{NO}_{2}\right)$ or ozone $\left(\mathrm{O}_{3}\right)$. As shown schematically in Fig. 1, the mixed-layer quantities are expected to be perfectly mixed by turbulence. Consequently, we can define the mixed-layer variables to be constant with height:

$$
\langle\phi\rangle=\frac{1}{h} \int_{\mathrm{S}}^{\mathrm{h}} \phi(z) \mathrm{d} z,
$$

with $\phi=\{\theta, q, S\}$ and "s" and "h" denote the surface and mixed-layer height. The equations governing $\langle\phi\rangle$ are derived by vertically integrating the one dimensional Reynolds averaged Navier-Stokes equations, resulting in:

$$
\frac{\partial\langle\phi\rangle}{\partial t}=\frac{\overline{w^{\prime} \phi_{\mathrm{s}}^{\prime}}-\overline{w^{\prime} \phi_{\mathrm{h}}^{\prime}}}{h}+S_{\phi}
$$

Here $\overline{w^{\prime} \phi^{\prime}}$ denotes a turbulent flux at the surface $(s)$ and the entrainment zone $(h)$ and $S_{\phi}$ contains additional source and sink terms, for chemical species the production and/or loss rates in chemical reactions. An additional term for advection has been omitted, but can easily be included in a similar manner like $S_{\phi}$. The mixed-layer top discontinuity $\Delta \phi$, marking the interface between the unstable mixed-layer and stable free troposphere, evolves in time as the combined result of mixed-layer growth and changes in the bulk quantity: $\frac{\partial \Delta \phi}{\partial t}=\frac{\partial \phi_{\mathrm{FT}}}{\partial t}-\frac{\partial\langle\phi\rangle}{\partial t}=\gamma_{\phi}\left(\frac{\partial h}{\partial t}+w_{\mathrm{s}}\right)-\frac{\partial\langle\phi\rangle}{\partial t}$,

where $\phi_{\mathrm{FT}}$ and $\gamma_{\phi}$ represent respectively the condition directly above the inversion and the free tropospheric lapse rate (Fig. 1). The mixed-layer grows due to entrainment, opposed by large scale vertical motions:

$\frac{\partial h}{\partial t}=w_{\mathrm{e}}+w_{\mathrm{s}}$,

where $w_{\mathrm{e}}$ and $w_{\mathrm{s}}$ represent the entrainment and subsidence velocity, the latter is defined as $w_{\mathrm{s}}=\left(-\nabla \times \mathbf{V}_{\mathrm{h}}\right) h$ with $\nabla \times$ $\mathbf{V}_{\mathrm{h}}$ the horizontal velocity divergence. The entrainment velocity is calculated as:

$w_{\mathrm{e}}=\frac{-\overline{w^{\prime} \theta^{\prime}}{ }_{\mathrm{v} ; \mathrm{h}}}{\Delta \theta_{\mathrm{v}}}$.

Note that virtual temperatures are used to include the influence of moisture on $-\overline{w^{\prime} \theta^{\prime}}$ v;h and to characterize the strength of the inversion $\left(\Delta \theta_{\mathrm{v}}\right)$ (Stull, 1988). In order to close this set of equations, the entrainment flux of (virtual) heat is parameterized as a negative fixed fraction $(\beta)$ of the surface heat flux:

${\overline{w^{\prime} \theta^{\prime}}}_{\mathrm{v} ; \mathrm{h}}=-\beta \overline{w^{\prime} \theta^{\prime}}{ }_{\mathrm{v} ; \mathrm{s}}$,

and written into Eq. (5). This relates the entrainment of not only heat, but also moisture and chemical species to the surface flux of heat and the thermodynamic structure as $w_{\mathrm{e}}$ is used to calculate the entrainment fluxes:

${\overline{w^{\prime} \phi^{\prime}}}_{\mathrm{h}}=-w_{\mathrm{e}} \Delta \phi$.

Buoyancy (mainly controlled by heat) is therefore a key variable, actively influencing the budgets of chemical reactive species. Explained in words, the tendencies of heat, moisture and chemical species depend on the mixing of any input at the surface (latent and sensible heat fluxes and, for chemical species, the emission or deposition fluxes) and the entrained air from the free troposphere over the mixed-layer depth. Depending on the sign of $\Delta \phi$ and therefore the difference between the mixed-layer and free troposphere, the influence of entrainment on the budget of a chemical species can be negative or positive. For instance, for the examples shown in Fig. 1., entrainment will decrease $\left\langle\mathrm{NO}_{2}\right\rangle$ (in the absence of source and sink terms) as air with a lower mixing ratio is entrained into the mixed-layer. For $\mathrm{O}_{3}$, the opposite occurs and entrainment will increase $\left\langle\mathrm{O}_{3}\right\rangle$.

\subsection{Representation of chemistry}

As a representation for the chemical reactions, two chemical reaction schemes are implemented in MXLCH: MOZART (Emmons et al., 2010) and an extended version of the reaction schemes used by Vilà-Guerau de Arellano et al. (2009, 
Table 1. Chemical reaction scheme used in the reduced scheme with $T$ the absolute temperature in Kelvin and $\chi$ the solar zenith angle. Firstorder reaction rates are in $\mathrm{s}^{-1}$, second-order reaction rates in $\mathrm{cm}^{3}$ molecule ${ }^{-1} \mathrm{~s}^{-1}$. In R19 $n=0$ (no OH-recycling), $\mathcal{P}$ depicts a product which is not further evaluated in the chemical reaction scheme. ISO refers to isoprene, where all its oxidation products (MVK; methyl vinyl ketone and MACR; methacrolein) are lumped into a single species MVK.

\begin{tabular}{|c|c|c|c|c|}
\hline Number & & & Reaction & Reaction Rate \\
\hline $\mathrm{R} 1$ & $\mathrm{O}_{3}+h v$ & $\rightarrow$ & $\mathrm{O}^{1} \mathrm{D}+\mathrm{O}_{2}$ & $3.00 \times 10^{-5} \times e^{\frac{-0.575}{\cos (x)}}$ \\
\hline $\mathrm{R} 2$ & $\mathrm{O}^{1} \mathrm{D}+\mathrm{H}_{2} \mathrm{O}$ & $\rightarrow$ & $2 \mathrm{OH}$ & $1.63 \times 10^{-10} \times e^{\frac{60}{T}}$ \\
\hline R3 & $\mathrm{O}^{1} \mathrm{D}+\mathrm{N}_{2}$ & $\rightarrow$ & $\mathrm{O}_{3}+\mathcal{P}$ & $2.15 \times 10^{-11} \times e^{\frac{110}{T}}$ \\
\hline $\mathrm{R} 4$ & $\mathrm{O}^{1} \mathrm{D}+\mathrm{O}_{2}$ & $\rightarrow$ & $\mathrm{O}_{3}$ & $3.30 \times 10^{-11} \times e^{\frac{55}{T}}$ \\
\hline R5 & $\mathrm{NO}_{2}+h v$ & $\rightarrow$ & $\mathrm{NO}+\mathrm{O}_{3}+\mathcal{P}$ & $1.67 \times 10^{-2} \times e^{\frac{-0.557}{\cos (x)}}$ \\
\hline R6 & $\mathrm{CH}_{2} \mathrm{O}+h v$ & $\rightarrow$ & $\mathrm{HO}_{2}+\mathcal{P}$ & $1.47 \times 10^{-4} \times e^{\frac{-0.555}{\cos (x)}}$ \\
\hline R7 & $\mathrm{OH}+\mathrm{CO}$ & $\rightarrow$ & $\mathrm{HO}_{2}+\mathcal{P}$ & $2.40 \times 10^{-13}$ \\
\hline $\mathrm{R} 8$ & $\mathrm{OH}+\mathrm{CH}_{4}$ & $\rightarrow$ & $\mathrm{CH}_{3} \mathrm{O}_{2}+\mathcal{P}$ & $2.45 \times 10^{-12} \times e^{\frac{-1775}{T}}$ \\
\hline R9 & $\mathrm{OH}+\mathrm{ISO}$ & $\rightarrow$ & $\mathrm{RO}_{2}$ & $1.00 \times 10^{-10}$ \\
\hline R10 & $\mathrm{OH}+\mathrm{MVK}$ & $\rightarrow$ & $\mathrm{HO}_{2}+\mathrm{CH}_{2} \mathrm{O}+\mathcal{P}$ & $2.40 \times 10^{-11}$ \\
\hline R11 & $\mathrm{OH}+\mathrm{HO}_{2}$ & $\rightarrow$ & $\mathrm{H}_{2} \mathrm{O}+\mathrm{O}_{2}$ & $4.80 \times 10^{-11} \times e^{\frac{250}{T}}$ \\
\hline $\mathrm{R} 12$ & $\mathrm{OH}+\mathrm{H}_{2} \mathrm{O}_{2}$ & $\rightarrow$ & $\mathrm{H}_{2} \mathrm{O}+\mathrm{HO}_{2}$ & $2.90 \times 10^{-12} \times e^{\frac{-160}{T}}$ \\
\hline $\mathrm{R} 13$ & $\mathrm{OH}+\mathrm{O}_{3}$ & $\rightarrow$ & $\mathrm{HO}_{2}+\mathrm{O}_{2}$ & $1.30 \times 10^{-12} \times e^{\frac{-956}{T}}$ \\
\hline R14 & $\mathrm{HO}_{2}+\mathrm{NO}$ & $\rightarrow$ & $\mathrm{OH}+\mathrm{NO}_{2}$ & $3.50 \times 10^{-12} \times e^{\frac{250}{T}}$ \\
\hline R15 & $\mathrm{CH}_{3} \mathrm{O}_{2}+\mathrm{NO}$ & $\rightarrow$ & $\mathrm{HO}_{2}+\mathrm{NO}_{2}+\mathrm{CH}_{2} \mathrm{O}+\mathcal{P}$ & $2.80 \times 10^{-12} \times e^{\frac{300}{T}}$ \\
\hline R16 & $\mathrm{RO}_{2}+\mathrm{NO}$ & $\rightarrow$ & $\mathrm{HO}_{2}+\mathrm{NO}_{2}+\mathrm{MVK}+\mathrm{CH}_{2} \mathrm{O}$ & $1.00 \times 10^{-11}$ \\
\hline $\begin{array}{l}\text { R17 } \\
\text { R18 }\end{array}$ & $\begin{array}{r}\mathrm{OH}+\mathrm{CH}_{2} \mathrm{O} \\
2 \mathrm{HO}_{2}\end{array}$ & $\rightarrow$ & $\begin{array}{l}\mathrm{HO}_{2}+\mathcal{P} \\
\mathrm{H}_{2} \mathrm{O}_{2}+\mathrm{O}_{2}\end{array}$ & $\begin{array}{l}5.50 \times 10^{-12} \times e^{\frac{125}{T}} \\
*\end{array}$ \\
\hline $\begin{array}{l}\text { R19 } \\
\text { R20 }\end{array}$ & $\begin{array}{r}\mathrm{CH}_{3} \mathrm{O}_{2}+\mathrm{HO}_{2} \\
\mathrm{RO}_{2}+\mathrm{HO}_{2}\end{array}$ & $\begin{array}{l}\rightarrow \\
\rightarrow\end{array}$ & $\begin{array}{l}\mathcal{P} \\
n \mathrm{OH}+\mathcal{P}\end{array}$ & $\begin{array}{l}4.10 \times 10^{-13} \times e^{\frac{750}{T}} \\
1.50 \times 10^{-11}\end{array}$ \\
\hline $\mathrm{R} 21$ & $\mathrm{OH}+\mathrm{NO}_{2}$ & $\rightarrow$ & $\mathrm{HNO}_{3}$ & $3.50 \times 10^{-12} \times e^{\frac{340}{T}}$ \\
\hline $\mathrm{R} 22$ & $\mathrm{NO}+\mathrm{O}_{3}$ & $\rightarrow$ & $\mathrm{NO}_{2}+\mathrm{O}_{2}$ & $3.00 \times 10^{-12} \times e^{\frac{-1500}{T}}$ \\
\hline $\mathrm{R} 23$ & $\mathrm{NO}_{2}+\mathrm{O}_{3}$ & $\rightarrow$ & $\mathrm{NO}_{3}+\mathrm{O}_{2}$ & $1.40 \times 10^{-13} \times e^{\frac{-2470}{T}}$ \\
\hline
\end{tabular}

2011); Ouwersloot et al. (2011), where the latter consists of a reduced mechanism of the chemical system. Despite being less complete in both the number of chemical species and reaction equations, the reduced scheme has a number of advantages over MOZART:

1. As the scheme contains less species and equations, the computational costs are minimized while the scheme still retains the essential components of the $\mathrm{O}_{3}-\mathrm{NO}_{\mathrm{x}}-\mathrm{VOC}-\mathrm{HO}_{\mathrm{x}}$ cycle (Vilà-Guerau de Arellano et al., 2011). Although computational time is no limiting factor when using a conceptual model like MXLCH, use of the reduced scheme can act as a validation before implementing it in for instance large-eddy simulation (e.g. Ouwersloot et al., 2011) where the number of reactions does put a serious constraint on the computational possibilities.
2. Using a limited number of species and reactions, the chemical system remains tractable, resulting in a better understanding of the main underlying chemical pathways.

3. By including less species, the degrees of freedom are reduced, resulting in less uncertainty in the initialization and boundary conditions (emission/deposition variability and initial properties of the mixed-layer and free troposphere) of the model.

The chemical reactions employed in the reduced scheme are presented in Table 1. The reaction rate coefficients are from the International Union of Pure and Applied Chemistry (IUPAC), Subcommittee for Gas Kinetic Data Evaluation (http://www.iupac-kinetic.ch.cam.ac.uk/). All chemical reactions are solved at each time step of $\mathrm{d} t=1 \mathrm{~s}$ for both the mixed-layer and free troposphere. We should note that, by using Reynolds averaged decomposition, a co-variance 
term between the reactants appears in the reaction equations (Ouwersloot et al., 2011). This term represents the effect of turbulence to mix the reactants. However, as shown by Dlugi et al. (2010) with measurements and by Ouwersloot et al. (2011) with numerical experiments in large-eddy simulation (LES), the influence of segregation on the reaction rates of e.g. $\mathrm{OH}$ and isoprene is only small (in the order of $10 \%$ ). Furthermore, Vilà-Guerau de Arellano et al. (2011) showed a reasonable agreement between MXLCH and LES, which explicitly takes the influence of segregation on the reactivities into account. In order to complete the discussion, it should be mentioned that Vinuesa and Vilá-Guerau de Arellano (2003) included a parameterization of the intensity of segregation in mixed-layer theory to account for the slow down of the reactivity because of the heterogeneous mixing. Given the uncertainties of the chemistry measurements and in view of the order of magnitude, this term is currently neglected in MXLCH.

\section{Case description}

Our numerical experiments are based on measurement data obtained during the DOMINO campaign, conducted at the Atmospheric Sounding Station - El Arenosillo $\left(37.1^{\circ} \mathrm{N}\right.$, $6.7^{\circ} \mathrm{W},+40 \mathrm{~m}$ a.m.s.l.), a platform of the Atmospheric Research and Instrumentation Branch of the Spanish National Institute for Aerospace Technology (INTA), dedicated to atmospheric measurements in the Southwest of Spain. All meteorological tower measurements were made $450 \mathrm{~m}$ from the sea coast and separated $70 \mathrm{~m}$ from the atmospheric chemistry observations. The vegetation is dominate by pine forest (Pinus pinea) with an average canopy height of $8 \mathrm{~m}$ growing above sandy soil. From the dataset, we selected the 23 November 2008 as it was an ideal day; characterized by a relative small influence of large synoptic scales and with lower build up of ozone (less than $10 \mathrm{ppb}$ in $10 \mathrm{~h}$ ). Furthermore, this day was in an intense observation period with high frequency balloon soundings (hourly, measuring the location, temperature, humidity and pressure) and comprehensive coverage of the chemical measurements. With high pressure over Spain (Azores High), it was a cloudless day with a moderate $\left(1-4 \mathrm{~m} \mathrm{~s}^{-1}\right)$ NNE flow in which an initially shallow stable boundary layer developed into a convective boundary layer with a depth of approximately $1400 \mathrm{~m}$ at 15:00 UTC. Figure 2 shows eight forward trajectories computed with the NOAA HYSPLIT model (Draxler and Rolph, 2011) using NCEP-GDAS as meteorological input files with $1 \times 1^{\circ}$ spatial resolution. The trajectories were calculated in the ABL (near surface, $100 \mathrm{~m}$ ) and free troposphere $(2000 \mathrm{~m})$, starting at the city of Sevilla and the industrial area near Huelva (petrochemical industry) at 08:00 UTC (ending at 13:00 UTC) and 12:00 UTC (ending at 17:00 UTC). In spite of the low resolution, the trajectories indicate that relative clean air was advected from these areas during 23 November. This is further

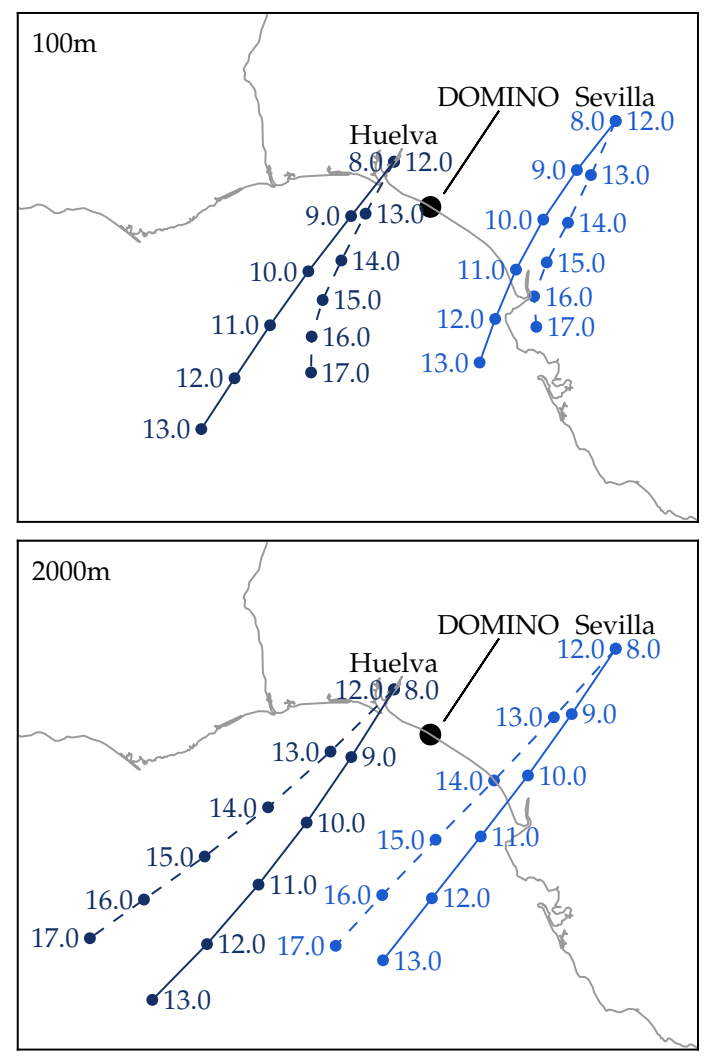

Fig. 2. Forward trajectories at $100 \mathrm{~m}$ and $2000 \mathrm{~m}$ calculated by the NOAA HYSPLIT model using NCEP-GDAS meteorology, starting at Sevilla and Huelva at 08:00 UTC (solid lines) and 12:00 UTC (dashed lines) on 23 November 2008. The black dot indicates the DOMINO measurement location at El Arenosillo. As a reference, the distance between the measurement site ("DOMINO") and Sevilla is $75 \mathrm{~km}$.

corroborated by the relative low $\mathrm{NO}_{\mathrm{x}}$ and $\mathrm{O}_{3}$ observations in Fig. 4. This ensures that the evolution in the observational chemical data is mainly controlled by local meteorological events: emission or deposition, chemical reactions or boundary layer dynamics, rather than long range transport.

The initial and boundary conditions used in MLXCH are presented in Tables 2 and 4 . The initial temperature and moisture profiles are based on the atmospheric soundings and meteorological data measured at $50 \mathrm{~m}$ a.g.l. from a tall tower $(100 \mathrm{~m})$ available at El Arenosillo. As no measurements of the surface heat and moisture fluxes are available, we impose typical values given the location and time of the year. In addition to the experiments with MXLCH, a second experiment is conducted with a box model to provide a first quantification of the influence of ABL dynamics. With both the sensible and latent heat flux set to zero, MXLCH behaves as a box model with a fixed height, temperature and moisture content, and no entrainment. By initializing the box model with time-averaged CBL-properties, the boundary conditions for chemical species (e.g. surface emission or deposition fluxes, 
Table 2. Initial and boundary conditions used in MXLCH. MXLCH is initiated at 07:00 UTC, $t$ is the elapsed time since the start of the simulation and $t_{d}$ is the time in seconds between 07:00-17:00 UTC.

\begin{tabular}{|c|c|}
\hline Property & Value \\
\hline $\begin{array}{l}\text { Initial mixed-layer height } \\
\quad h[\mathrm{~m}]\end{array}$ & 500 \\
\hline $\begin{array}{l}\text { Horizontal velocity divergence } \\
\qquad \nabla \times \mathbf{V}_{\mathrm{h}}\left[\mathrm{s}^{-1}\right]\end{array}$ & $5 \times 10^{-6}$ \\
\hline $\begin{array}{l}\text { Geostrophic wind } \\
\quad U_{\mathrm{g}}, V_{\mathrm{g}}\left[\mathrm{m} \mathrm{s}^{-1}\right]\end{array}$ & $(0,0)$ \\
\hline $\begin{array}{l}\text { Surface sensible heat flux } \\
\overline{w^{\prime} \theta^{\prime}}\left[\mathrm{K} \mathrm{m} \mathrm{s}^{-1}\right]\end{array}$ & $0.22 \sin \left(\pi t / t_{d}\right)$ \\
\hline $\begin{array}{l}\text { Entrainment/surface heat-flux ratio } \\
\qquad \beta=-\overline{w^{\prime} \theta^{\prime}}{ }_{\mathrm{h}} / \overline{w^{\prime} \theta^{\prime}} \mathrm{s}[-]\end{array}$ & 0.2 \\
\hline $\begin{array}{l}\text { Initial mixed-layer potential temperature } \\
\qquad\langle\theta\rangle[\mathrm{K}]\end{array}$ & 287 \\
\hline $\begin{array}{l}\text { Initial free-troposphere potential temperature } \\
\theta_{\mathrm{FT}}[\mathrm{K}]\end{array}$ & 288.5 \\
\hline $\begin{array}{l}\text { Potential temperature lapse rate free troposphere } \\
\quad \gamma_{\theta}\left[\mathrm{K} \mathrm{m}^{-1}\right]\end{array}$ & 0.006 \\
\hline $\begin{array}{l}\text { Surface latent heat flux } \\
\qquad \overline{w^{\prime} q^{\prime}}{ }_{\mathrm{s}}\left[\mathrm{g} \mathrm{kg}^{-1} \mathrm{~m} \mathrm{~s}^{-1}\right]\end{array}$ & $0.03 \sin \left(\pi t / t_{d}\right)$ \\
\hline $\begin{array}{l}\text { Initial mixed-layer specific humidity } \\
\quad\langle q\rangle\left[\mathrm{g} \mathrm{kg}^{-1}\right]\end{array}$ & 5.3 \\
\hline $\begin{array}{l}\text { Initial free-troposphere specific humidity } \\
\qquad q_{\mathrm{FT}}\left[\mathrm{g} \mathrm{kg}^{-1}\right]\end{array}$ & 4.5 \\
\hline $\begin{array}{l}\text { Specific humidity lapse rate free troposphere } \\
\qquad \gamma_{\theta}\left[\mathrm{g} \mathrm{kg}^{-1} \mathrm{~m}^{-1}\right]\end{array}$ & -0.0012 \\
\hline
\end{tabular}

Table 4) can be kept identical to those in MXLCH. This ensures a fair comparison between MXLCH and the box model and with that, the influence of ABL dynamics. The different experiments are summarized in Table 3. The initial mixedlayer and free tropospheric mixing ratios and surface forcings (emission/deposition) of chemical species are shown in Table 4. The initial mixing ratios are based on the DOMINO measurements, obtained at 10-12 m a.g.l. Although surfaceemitted (or deposited) species typically have a higher (lower) mixing-ratio near the surface, the difference with the bulkaveraged mixing-ratios and tendencies is in general small and within the uncertainty of the measurements (Vilà-Guerau de Arellano et al., 2011). All other species (except for molecular oxygen and nitrogen) are initialized at zero.

\section{Results}

\subsection{Temporal evolution of dynamics and chemistry}

The temporal evolution of the mixed-layer height $(h)$ and slab averaged potential temperature $(\theta)$ and specific humidity $(q)$ is shown in Fig. 3a-c. When around 09:00 UTC the surface sensible heat flux breaks the ground inversion by heating the ABL, the mixed-layer experiences a rapid growth of approximately $200 \mathrm{~m} \mathrm{~h}^{-1}$ between 09:00 UTC and 12:00 UTC. As the mixed-layer grows, air with properties of
Table 3. Overview experiments.

\begin{tabular}{lll}
\hline Name & Dynamics & Chemistry \\
\hline BOX750 & NONE & Reduced \\
MOZART & MXLCH & MOZART \\
REDUCED & MXLCH & Reduced \\
\hline
\end{tabular}

the free troposphere is entrained into the mixed-layer, causing an increase in potential temperature (entrainment of relative warm air) and decrease in specific humidity (entrainment of dry air). Comparison with the measurements show that the mixed-layer model correctly represents the dynamical evolution of the ABL, where subsidence (Eq. 4, Table 2) decreases the mixed-layer growth by about $200 \mathrm{~m}$ throughout the day. Especially the accurate representation of the mixedlayer height is crucial for the budgets of chemical species, not only because of its influence on entrainment, but also as $h$ is the mixing-depth of any input or loss at the surface or mixed-layer top (Eq. 2). This encourages frequent probing of the atmosphere (like e.g. during DOMINO with balloon soundings at a $1 \mathrm{~h}$ interval) as the mixed-layer height is calculated as the maximum temperature gradient of the upper air soundings, and frequent measurements are needed to capture the rapid development in the early morning. In addition to the thermodynamic variables, we show in Fig. $3 \mathrm{~d}$ the photolysis rate of $\mathrm{NO}_{2}$, a quantity driven by ultraviolet radiation. To calculate the photolysis rate of $\mathrm{NO}_{2}$, we use the empirical expression of Wiegand and Bofinger (2000). Both MOZART and the reduced scheme correctly reproduce the measured photolysis rate of $\mathrm{NO}_{2}$ and in addition (not shown), produce similar results as the TUV model (Madronich et al., 2011) for the photolysis rates of $\mathrm{O}_{3}$ and $\mathrm{CH}_{2} \mathrm{O}$.

Figure 4 shows the diurnal variation of $\mathrm{O}_{3}, \mathrm{NO}, \mathrm{NO}_{2}$ and $\mathrm{HNO}_{3}$. Although the tendencies are similar, the results obtained with experiment BOX750 tend to overestimate the mixing ratio evolution. This is the combined effect of not taking mixed-layer growth and entrainment, the exchange between the ABL and free troposphere, into account. MXLCH with both MOZART and the reduced scheme is capable of reproducing the measured mixing ratios. The mixing ratio of $\mathrm{O}_{3}$ is slightly underestimated with MOZART and $\mathrm{NO}_{2}$ slightly overestimated using the reduced chemistry scheme. In spite of being a reduced scheme, the scheme presented in Table 1 is able to reproduce the observational trend of $\mathrm{O}_{3}$, $\mathrm{NO}$ and $\mathrm{NO}_{2}$ and same characteristic ratios like $\mathrm{NO}_{2} / \mathrm{NO} \approx 2-3$. This indicates that in regimes and regions where ozone increases smoothly, the scheme performs satisfactorily. Again, given the differences between the box model and the measurements/MXLCH, it needs to be stressed that ABL dynamics plays a key role in reproducing and understanding the measured mixing ratios.

The satisfactory results of the reduced scheme are further corroborated by the intercomparison of the isoprene, 
Table 4. Initial mixing ratio in both MOZART and the reduced scheme in the mixed-layer $(\langle S\rangle)$ and free troposphere $\left(S_{\mathrm{FT}}\right)$, and surface emission or deposition. All other species except for molecular oxygen and nitrogen are initialized at zero. The chemistry scheme is initialized at 07:00 UTC, $t$ is the elapsed time since the start of the simulation and $t_{d}$ is the time in seconds between 07:00-17:00 UTC.

\begin{tabular}{cccccccc}
\hline & $\mathrm{O}_{3}$ & $\mathrm{NO}$ & $\mathrm{NO}_{2}$ & $\mathrm{CH}_{4}$ & $\mathrm{ISO}$ & $\mathrm{CO}$ & $\mathrm{H}_{2} \mathrm{O}_{2}$ \\
\hline$\langle S\rangle[\mathrm{ppb}]$ & 31 & 0 & 0.6 & 1724 & 0 & 105 & 0.1 \\
$S_{\mathrm{FT}}[\mathrm{ppb}]$ & 39 & 0 & 0 & 1724 & 0 & 105 & 0.1 \\
\hline$w^{\prime} S^{\prime}\left[\mu \mathrm{g} \mathrm{m}^{-2} \mathrm{~s}^{-1}\right]$ & 0 & 0.04 & $\mathrm{a}$ & 0 & $\mathrm{~b}$ & 0 & 0 \\
\hline
\end{tabular}

${ }^{\text {a }}$ Deposition flux of $\mathrm{NO}_{2}$ is calculated as $-v_{\mathrm{C}} \mathrm{C}_{\mathrm{NO}_{2}}$ with $v_{\mathrm{C}}=0.015 \mathrm{~m} \mathrm{~s}^{-1}$

$\mathrm{b} \overline{w^{\prime} \mathrm{ISO}^{\prime}}=0.09 \cdot \sin \left(\pi t / t_{d}\right)$

$\mathrm{OH}, \mathrm{HO}_{2}$ and $\mathrm{H}_{2} \mathrm{O}_{2}$ mixing-ratios in Fig. 5. For isoprene, MOZART and the reduced scheme both have different tendencies compared with the few observations, but the mixing ratios are of a similar order. For $\mathrm{OH}, \mathrm{HO}_{2}$ and $\mathrm{H}_{2} \mathrm{O}_{2}$, both MOZART and the reduced scheme are close to the measured data where, on average, MOZART underestimates the mixing ratios due to the introduction of additional reactions that destroy $\mathrm{OH}$. However, it needs to be stressed that the measured $\mathrm{OH}$ mixing-ratios are upper-limit values, possibly overestimating the mixing ratio by up to a factor two (Sörgel et al., 2011). The difference in $\mathrm{OH}, \mathrm{HO}_{2}$ and $\mathrm{H}_{2} \mathrm{O}_{2}$ between MXLCH and the box model can be explained by the difference in the NO temporal pattern (Fig. 4). Although it is expected that $\mathrm{OH}$, with its high reactivity, should be insensitive to ABL dynamics, the mixing ratio is indirectly influenced through (amongst others, but predominantly) R14, which also explains the relative decrease of $\mathrm{HO}_{2}$ in the box model. It should be mentioned that although we are not accounting for key chemical pathways like the formation of OH from HONO (Sörgel et al., 2011), our findings provide a comprehensible evolution of reactants in the ABL. In this respect, although we are missing the relatively large concentration gradients near the surface (an example is given in Fig. 3 of Vilà-Guerau de Arellano et al., 2011), we take advantage of the rapid mixing efficiency of the ABL, driven by convective turbulence.

\subsection{Budgeting of chemical reactants}

MXLCH enables us to further determine the individual contributions of emission/deposition, chemical transformation and entrainment to the evolution of the (reactive) species, i.e. the different terms of Eq. (2). We selected four species to examine the variation in time of the contribution of both dynamics and chemistry. The dynamic part is here defined as the mixing of both surface emissions/deposition and the entrained air over the mixed-layer depth $h$ whereas the chemical contribution is the net production or loss rate from the equations in Table 1:

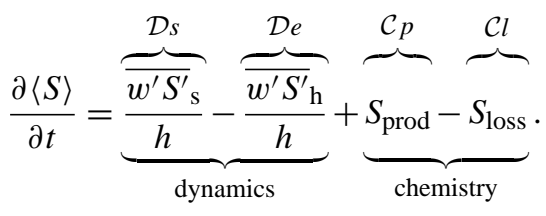

Figure 6 shows the budgets of $\mathrm{O}_{3}, \mathrm{NO}, \mathrm{NO}_{2}$ and $\mathrm{OH}$. As Fig. 6a shows, the net $\mathrm{O}_{3}$ tendency is positive throughout almost the entire day (see Fig. 4a) with a maximum increase in $\mathrm{O}_{3}$ around 09:30 UTC. The peak is closely related to the maximum in entrainment $(\mathcal{D} e)$ of ozone originating in the free troposphere, at this time caused by (1) the rapid growing mixed-layer (Fig. 3) and (2) the relative large difference in mixing ratio between the mixed-layer and free troposphere $\left(\Delta \mathrm{O}_{3} \approx 7 \mathrm{ppb}\right)$. When during the day the $\mathrm{O}_{3}$ mixing ratio increases (decreasing $\Delta \mathrm{O}_{3}$ towards zero) and the mixed-layer growth decreases, the contribution of entrainment relative to the chemical term decreases to zero around 14:00 UTC. From 08:00 UTC onwards the net chemical tendency is positive and equals the contribution by entrainment around 11:00 UTC. After 13:00 UTC the total ozone tendency is mainly driven by chemical reactions. This means that the total $\mathrm{O}_{3}$ tendency is mainly controlled by dynamics during the morning growth of the $\mathrm{ABL}$ and by chemistry in the afternoon.

The tendency of NO, shown in Fig. 6b, is positive up to 09:30 UTC and negative afterwards, in agreement with the peak observed in Fig. 4b. Since the initial mixing ratios and thus initial $\Delta \mathrm{NO}$ is zero, the relative contribution of entrainment to the total tendency is small. Only when the mixed-layer mixing ratio has increased towards its maximum around 10:00 UTC, growth of the mixed-layer causes entrainment of air with a relative low mixing ratio $(\Delta \mathrm{NO} \approx$ $-0.14 \mathrm{ppb}$ ), resulting in a small (negative) contribution to the total tendency. The total tendency is therefore the result of a balance between the surface emission and the net chemical loss. Despite being forced with a fixed surface emission (Table 4), Ds decreases throughout the day as the mixed-layer grows, because this term is inversely proportional to $h$ (see Eq. 8). This demonstrates that, without having a strong influence of entrainment, $\mathrm{ABL}$ dynamics still influences the 

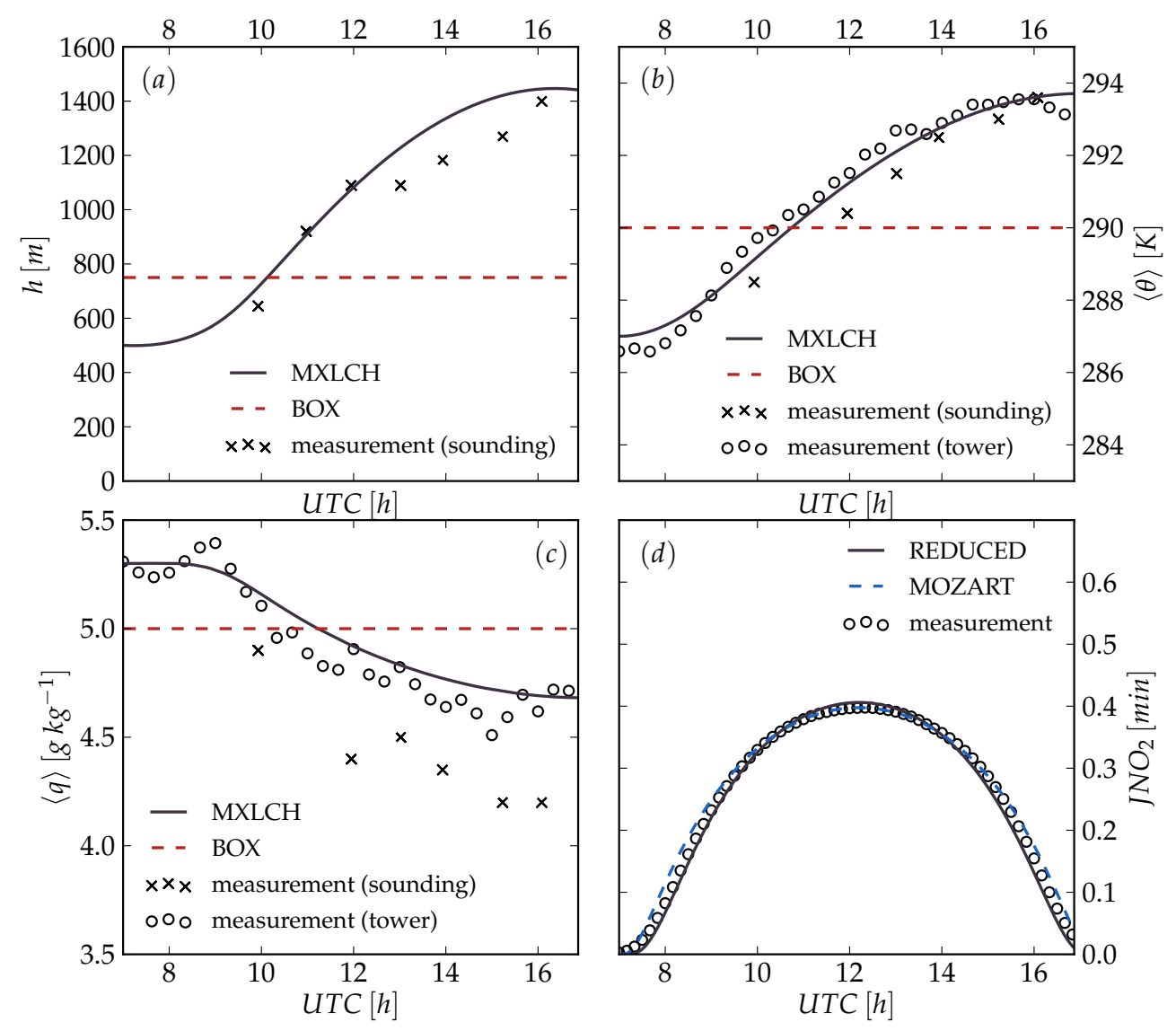

Fig. 3. Time evolution of the (a) mixed-layer height, (b) slab averaged potential temperature, (c) slab averaged specific humidity and (d) photolysis rate of $\mathrm{NO}_{2}$, compared to the measurements. In addition to the results of MXLCH, the fixed conditions of the box model are indicated.

tendencies of chemical species, as shown by the first RHS term of Eq. (8).

Figure $6 \mathrm{c}$ shows the budget of $\mathrm{NO}_{2}$. With a lower mixing ratio in the free troposphere, entrainment results in a decrease of $\mathrm{NO}_{2}$ which, like for ozone, is the strongest around 09:30 UTC. At the same time, deposition causes an extra loss of $\mathrm{NO}_{2}$. With the deposition calculated as $-v_{\mathrm{C}} \mathrm{C}_{\mathrm{NO}_{2}}$ with $v_{\mathrm{C}}$ constant (Table 4), the contribution of deposition decreases as both the $\mathrm{NO}_{2}$ mixing ratio decreases and the mixed-layer grows. Combined, the dynamical contribution causes a strong negative tendency during the day. Chemical transformations counter the dynamical contribution. However only during the morning (when the contribution of entrainment is still small) and late afternoon (when the mixedlayer reaches its maximum height) the net chemical production is sufficient to create a net positive tendency of $\mathrm{NO}_{2}$.

For faster reacting species like $\mathrm{OH}$ in Fig. 6d, the tendency is mostly controlled by chemical production and loss. This indicates that, for species with a short lifetime or high reactivity, the chemical part of Eq. (8) dominates and the influence of ABL dynamics decreases. Note however that the $\mathrm{OH}$ budget in Fig. 6d is also influenced by entrainment. This can be interpreted as an instantaneous exchange of air masses between the free troposphere and ABL. However, due to the high reactivity, the $\mathrm{OH}$ mixing ratio is still largely determined by surface sources and sinks. This subject will be studied in more detail in the next section.

\subsection{Time scales of turbulence and chemistry}

To further substantiate the relative influence of mixed-layer dynamics compared to chemistry, and to provide a more robust quantification of their relative importance, we examine further the diurnal variability in terms of the characteristic time scales on which the different species and turbulence are acting. The Damköhler number (Damköhler, 1940), for mixing at large scales defined as the ratio of the typical turbulence time scale to the time scale of chemistry (VilàGuerau de Arellano, 2003), is the key dimensionless number to distinguish the influence of turbulence from chemistry:

$D a_{\mathrm{S}}=\frac{\tau_{t}}{\tau_{\mathrm{c} ; \mathrm{S}}} ; \tau_{t}=\frac{h}{w_{*}} ; \tau_{\mathrm{c} ; \mathrm{S}}=\frac{c_{\mathrm{S}}}{\mathcal{C}_{\mathrm{l}}}$,

with $\tau_{t}$ the time scale of turbulence, $\tau_{\mathrm{c} ; \mathrm{S}}$ the time scale of chemical species $S, c_{\mathrm{S}}$ the concentration of species $S$ and $\mathcal{C}_{1}$ the chemical loss rate of species $S . w_{*}$ is the convective 

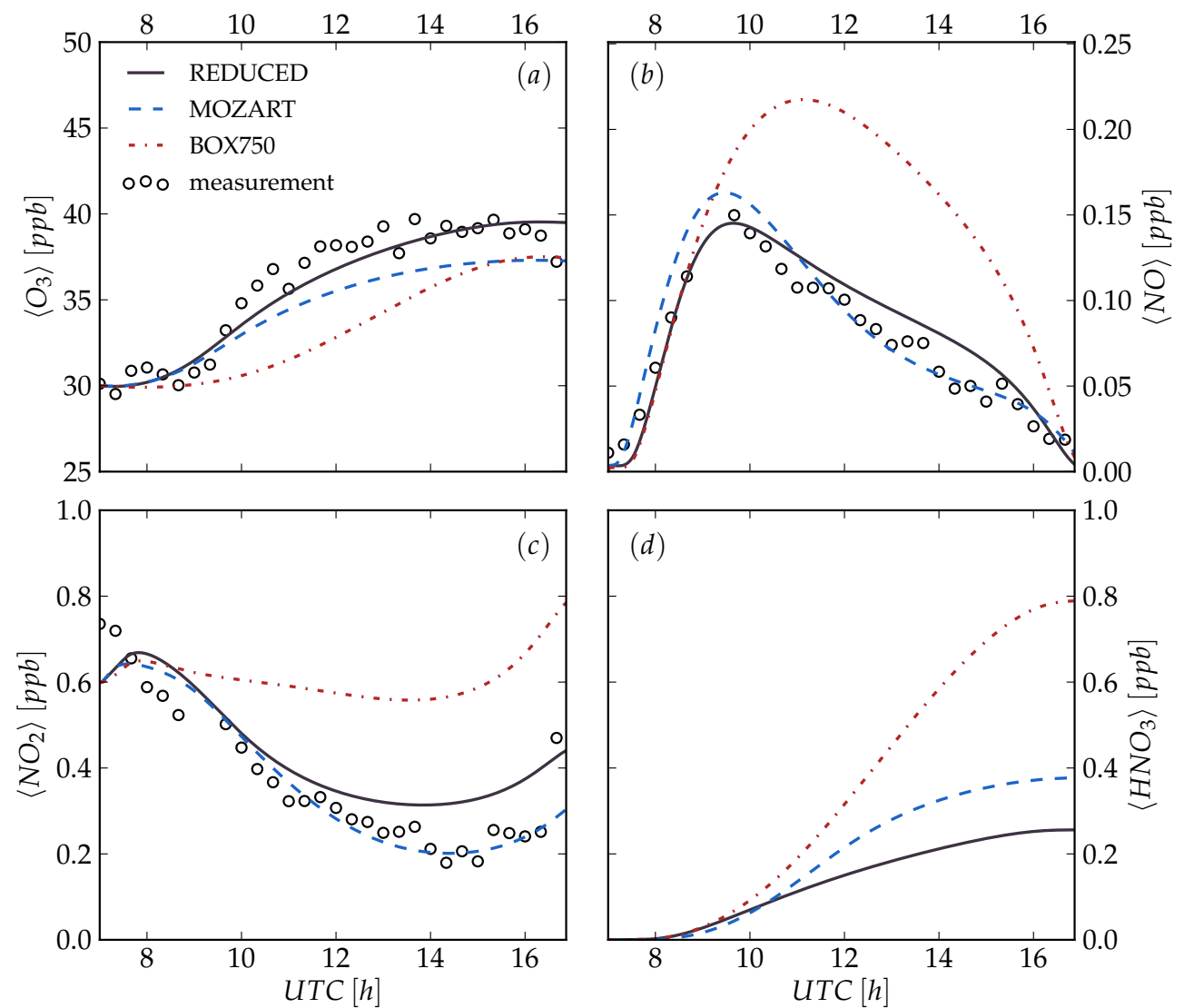

Fig. 4. Measured and modeled mixed-layer mixing ratios of $\mathrm{O}_{3}, \mathrm{NO}, \mathrm{NO}_{2}$ and $\mathrm{HNO}_{3}$ as measured and modeled with $\mathrm{MXLCH}$ (using both MOZART and the reduced chemical scheme) and the box model (using the reduced chemistry scheme).

velocity scale, defined as (Stull, 1988):

$w_{*}=\sqrt[3]{\frac{g h}{\left\langle\theta_{\mathrm{v}}\right\rangle} \overline{w^{\prime} \theta^{\prime}} \mathrm{v} ; \mathrm{s}}$

where $g$ is the gravitational acceleration. The time scale $\tau_{t}$ thus increases as the mixed-layer grows, while a stronger virtual heat flux $\left(\overline{w^{\prime} \theta^{\prime}}\right.$ v;s $)$ enhances turbulent mixing and therefore decreases the time scale. Based on the Damköhler number we can define the following regimes:

- $D a_{\mathrm{S}} \lesssim 0.1-$ Slow chemistry where the mixing ratio is controlled by emission/deposition and ABL dynamics

- $0.1 \lesssim D a_{\mathrm{S}} \lesssim 10$ - Moderate chemistry where the mixing ratio is governed by $\mathrm{ABL}$ dynamics and chemical reactions

- $D a_{\mathrm{S}} \gtrsim 10$ - Fast chemistry where the mixing ratio is determined by chemical reactions.

For $D a_{\mathrm{S}} \gtrsim 10$, the influence of ABL dynamics is negligible and Eq. (8) reduces to only the chemical contributions. In contrast, $D a_{\mathrm{S}} \lesssim 0.1$ indicates that the contribution of chemical reactions is relatively small compared to ABL dynamics or large-scale forcings. For $0.1 \lesssim D a_{\mathrm{S}} \lesssim 10$, chemistry and dynamics interact and both the dynamical and chemical terms of Eq. (8) needs to be taken into account. Using MXLCH, we are able to calculate the time scales of turbulence and the individual chemical species and thus indicate the relative importance of dynamics and chemistry.

Figure 7 shows the time scale $\tau$ for both the convective ABL ("turbulence") and a number of fast and slow reaction species. For the analyzed day during DOMINO the time scale of the ABL, $\tau_{t}$, increases from $\sim 400 \mathrm{~s}$ at 09:00 UTC to $\sim 1000 \mathrm{~s}$ at 16:00 UTC. The slowest reacting species, CO, has a time scale on the order of 10 days, resulting in a $D a_{\mathrm{S}} \ll 0.1$. This indicates that $\mathrm{CO}$ is mainly controlled by atmospheric turbulence and transport. In contrast, $\mathrm{OH}$ has a time scale of seconds or less, resulting in $D a_{\mathrm{S}} \gg 10$. This confirms the findings of Fig. $6 \mathrm{~d}$, where the $\mathrm{OH}$ budget was mainly determined by the chemical transformations. Closely connected with the chemical lifetime of $\mathrm{OH}$ is the $\mathrm{OH}$-reactivity; the inverse of the lifetime (e.g. Di Carlo et al., 2004; Lelieveld et al., 2008; Sinha et al., 2008). During DOMINO, the reactivity of $\mathrm{OH}$ was directly measured with at 23 November values in the order of $40 \mathrm{~s}^{-1}$ (Sinha et al., 2012). With average reactivities of $1.4 \mathrm{~s}^{-1}$ (reduced scheme) and $2 \mathrm{~s}^{-1}$ (MOZART), MXLCH underestimates the reactivity. As the 

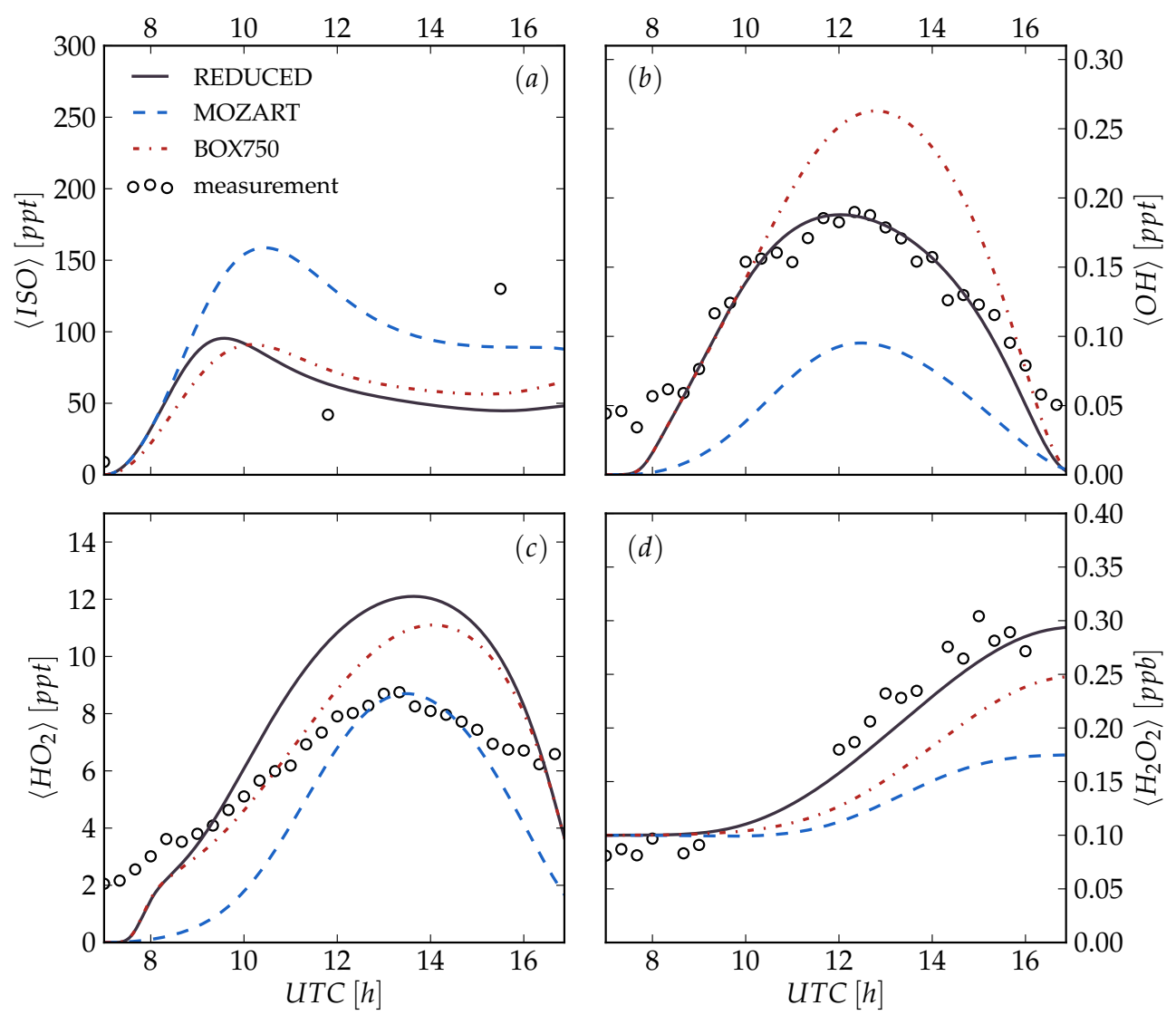

Fig. 5. Measured and modeled mixed-layer mixing ratios of Isoprene, $\mathrm{OH}, \mathrm{HO}_{2}$ and $\mathrm{H}_{2} \mathrm{O}_{2}$ as measured and modeled with $\mathrm{MXLCH}$ (using both MOZART and the reduced chemical scheme) and the box model (using the reduced chemistry scheme).

modeled $\mathrm{OH}$ mixing ratio fits well to the measurements (Fig. 5), this indicates that both chemical schemes are missing chemical pathways related to the production and destruction of $\mathrm{OH}$. This is still an open issue, possibly caused by an incomplete initialization of anthropogenic volatile organic compounds (VOC). Intermediate species like $\mathrm{O}_{3}, \mathrm{NO}$ and $\mathrm{NO}_{2}$ act on a time scale of minutes to hours, within \pm one order of magnitude of the typical time scale of the ABL, again corroborating the need to take dynamics and chemical transformations simultaneously into account.

\section{Conclusions}

In this study we used a mixed-layer model coupled to chemical reaction schemes to systematically study the influence of atmospheric boundary layer (ABL) dynamics on the time evolution of chemistry. We selected a representative day during the DOMINO measurement campaign and designed numerical experiments to determine the performance of two chemical schemes with different complexity (MOZART-4 and a reduced mechanism of this chemical system) under realistic dynamical conditions. Additional experiments with a box model, which neglects the influence of ABL dynam- ics, display an underestimation of the $\mathrm{O}_{3}$ mixing ratios, and an overestimation in the mixing ratios of most other chemical species. The mixed-layer model with both MOZART and the reduced reaction scheme performs satisfactory, reproducing the measured mixing ratios of key chemical species like $\mathrm{O}_{3}$ and $\mathrm{NO}_{\mathrm{x}}$. This indicates that, in conditions characterized by a low $\mathrm{NO}_{\mathrm{x}}$ regime and small $\mathrm{O}_{3}$ tendencies, the reduced scheme is capable of reproducing the $\mathrm{O}_{3}-\mathrm{NO}_{\mathrm{x}}-\mathrm{VOC}-\mathrm{HO}_{\mathrm{x}}$ diurnal cycle. Under these conditions, the reduced scheme is a useful, more comprehensible and computationally less expensive alternative for complex schemes like MOZART, for e.g. use in large-eddy simulation.

By studying the individual contribution of emission/deposition, chemical transformation, mixed-layer growth and entrainment to the evolution of the reactive species, it is found that for species like $\mathrm{O}_{3}, \mathrm{NO}, \mathrm{NO}_{2}$, the contribution of boundary layer processes is of the same order as the contribution of chemical transformations. Both $\mathrm{O}_{3}$ and $\mathrm{NO}_{2}$ are strongly controlled by entrainment of relatively $\mathrm{O}_{3}$-rich and $\mathrm{NO}_{2}$ poor air originated in the free troposphere. The change in mixed-layer height, the depth over which any input or loss at the surface or mixed-layer top is distributed, was shown to be important for the budget of NO. 

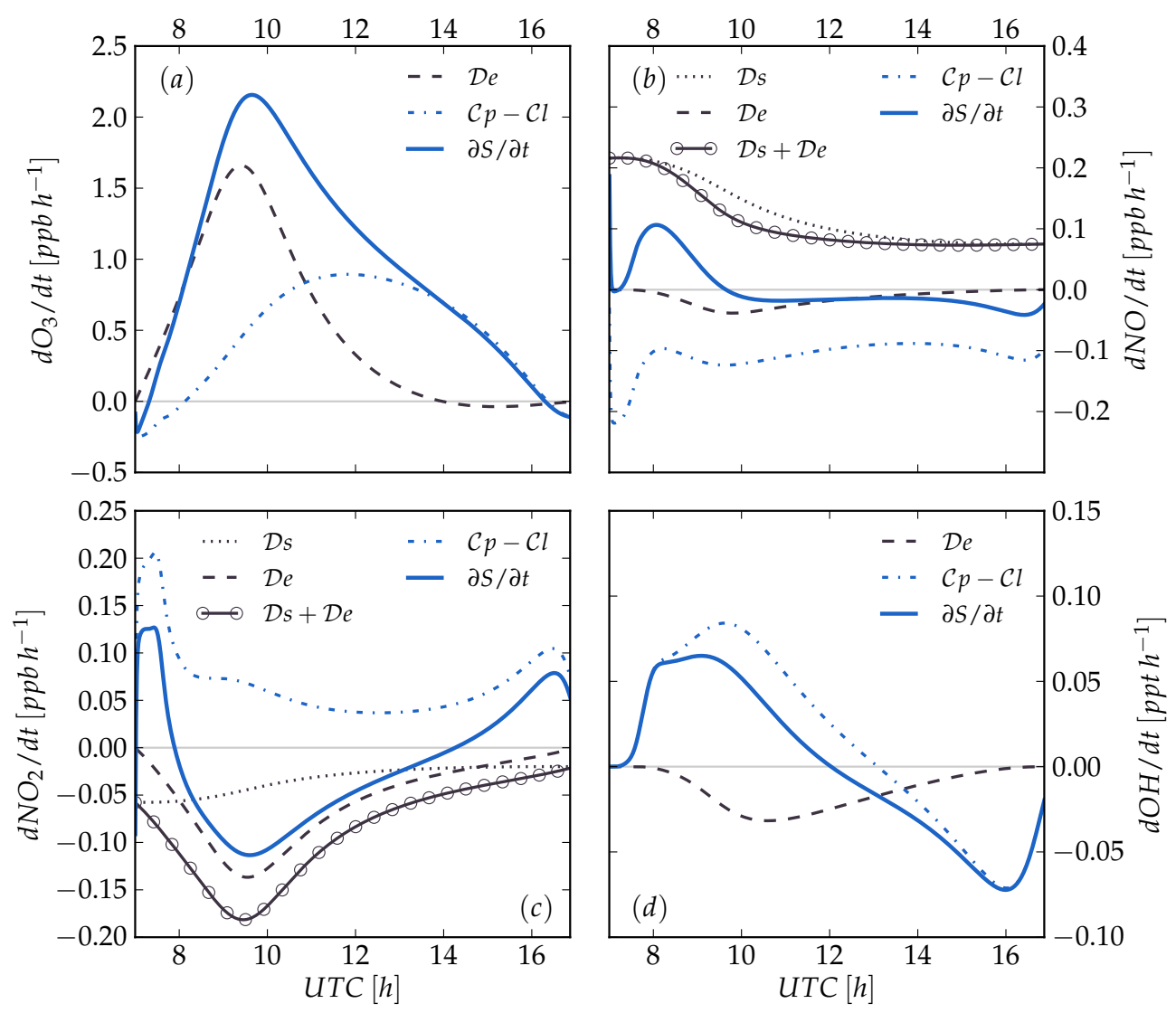

Fig. 6. Individual budget terms of Eq. (8) for $\mathrm{O}_{3}, \mathrm{NO}, \mathrm{NO}_{2}$ and $\mathrm{OH}$. The labels of the individual terms refer to the notation defined in Eq. (8).

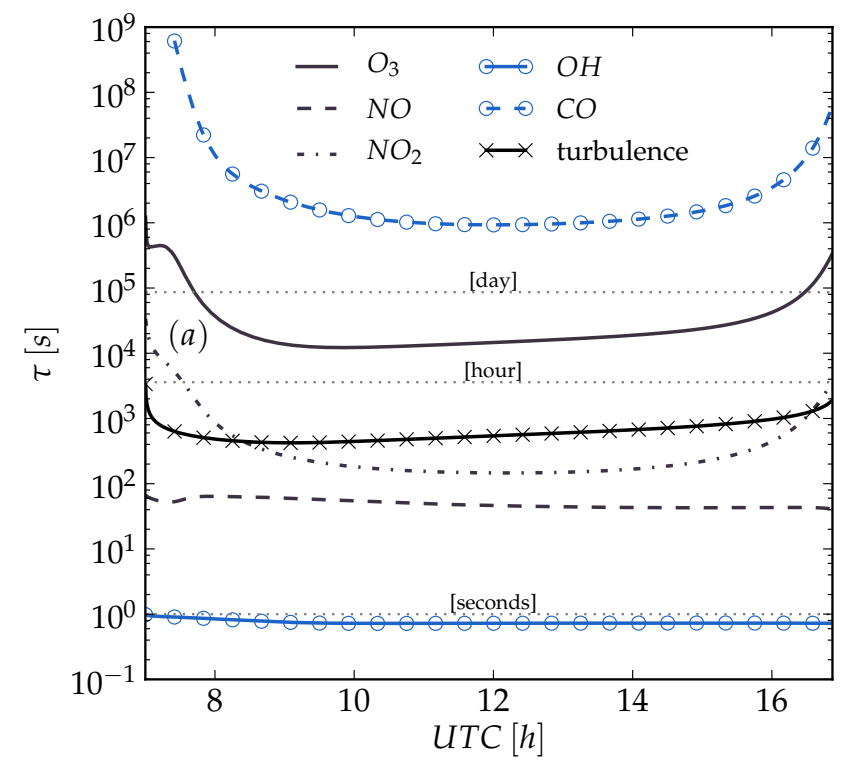

Fig. 7. Lifetimes of key chemical species and the convective ABL.
By comparing the lifetime of chemically active species with the boundary layer mixing time through the dimensionless Damköhler number, we demonstrated an effective method to obtain a first estimate of the relevance of dynamics and chemistry. When classified into three regimes, the Damköhler number provides a measure of whether chemistry is controlled by chemical transformations or ABL-dynamics. When calculated for a number of fast $(\mathrm{OH})$, intermediate $\left(\mathrm{O}_{3}\right.$, $\mathrm{NO}, \mathrm{NO}_{2}$ ) and slow $(\mathrm{CO})$ reacting species, this method confirmed the impact of ABL-dynamics on the time evolution of chemical active species.

Due to its simplicity and transparency, the mixed-layer model (MXLCH) used in this study can act as a useful tool towards a better understanding of (1) the main chemical pathways and processes that govern the temporal evolution of chemistry and (2) a better understanding of the results obtained during measurement campaigns. Also, gaining a better understanding of the core physical and chemical processes involved might be beneficial for the development of new measurement campaigns or strategies, or to understand new chemical pathways. MXLCH is available from the authors upon request. 
Edited by: R. Holzinger

\section{References}

Betts, A. K.: Non-precipitating convection and its parameterization, Q. J. Roy. Meteorol. Soc., 99, 178-196, 1973.

Crowley, J. N., Thieser, J., Tang, M. J., Schuster, G., Bozem, H., Beygi, Z. H., Fischer, H., Diesch, J.-M., Drewnick, F., Borrmann, S., Song, W., Yassaa, N., Williams, J., Pöhler, D., Platt, U., and Lelieveld, J.: Variable lifetimes and loss mechanisms for $\mathrm{NO}_{3}$ and $\mathrm{N}_{2} \mathrm{O}_{5}$ during the DOMINO campaign: contrasts between marine, urban and continental air, Atmos. Chem. Phys., 11, 10853-10870, doi:10.5194/acp-11-10853-2011, 2011.

Damköhler, G.: Influence of turbulence on the velocity flames in gas mixtures, Z. Elektrochem., 46, 601-626, 1940.

Di Carlo, P., Brune, W. H., Martinez, M., Harder, H., Lesher, R., Ren, X., Thornberry, T., Carroll, M. A., Young, V., Shepson, P. B., Riemer, D., Apel, E., and Campbell, C.: Missing OH Reactivity in a Forest: Evidence for Unknown Reactive Biogenic VOCs, Science, 304, 722-725, 2004.

Diesch, J.-M., Drewnick, F., Zorn, S. R., von der WeidenReinmüller, S.-L., Martinez, M., and Borrmann, S.: Variability of aerosol, gaseous pollutants and meteorological characteristics associated with changes in air mass origin at the SW Atlantic coast of Iberia, Atmos. Chem. Phys., 12, 3761-3782, doi:10.5194/acp12-3761-2012, 2012.

Dlugi, R., Berger, M., Zelger, M., Hofzumahaus, A., Siese, M., Holland, F., Wisthaler, A., Grabmer, W., Hansel, A., Koppmann, R., Kramm, G., Möllmann-Coers, M., and Knaps, A.: Turbulent exchange and segregation of $\mathrm{HO}_{\mathrm{x}}$ radicals and volatile organic compounds above a deciduous forest, Atmos. Chem. Phys., 10, 6215-6235, doi:10.5194/acp-10-6215-2010, 2010.

Draxler, R. R. and Rolph, G. D.: HYSPLIT (HYbrid Single-Particle Lagrangian Integrated Trajectory) Model access via NOAA ARL READY Website (http://ready.arl.noaa.gov/HYSPLIT. php), NOAA Air Resources Laboratory, Silver Spring, MD, 2011.

Emmons, L. K., Walters, S., Hess, P. G., Lamarque, J.-F., Pfister, G. G., Fillmore, D., Granier, C., Guenther, A., Kinnison, D., Laepple, T., Orlando, J., Tie, X., Tyndall, G., Wiedinmyer, C., Baughcum, S. L., and Kloster, S.: Description and evaluation of the Model for Ozone and Related chemical Tracers, version 4 (MOZART-4), Geosci. Model Dev., 3, 43-67, doi:10.5194/gmd3-43-2010, 2010.

Ganzeveld, L., Eerdekens, G., Feig, G., Fischer, H., Harder, H., Königstedt, R., Kubistin, D., Martinez, M., Meixner, F. X., Scheeren, H. A., Sinha, V., Taraborrelli, D., Williams, J., VilàGuerau de Arellano, J., and Lelieveld, J.: Surface and boundary layer exchanges of volatile organic compounds, nitrogen oxides and ozone during the GABRIEL campaign, Atmos. Chem. Phys., 8, 6223-6243, doi:10.5194/acp-8-6223-2008, 2008.

Gao, W., Weseley, M., and Doskey, P.: Numerical modeling of the turbulent diffusion and chemistry of $\mathrm{NO}_{\mathrm{x}}, \mathrm{O}_{3}$, isoprene, and other reactive trace gases in and above a forest canopy, J. Geophys. Res., 98, 18339-18353, 1993.

Lelieveld, J., Butler, T., Crowley, J., Dillon, T., Fischer, H., Ganzeveld, L., Harder, H., Lawrence, M., Martinez, M., Taraborrelli, D., and Williams, J.: Atmospheric oxidation capacity sustained by a tropical forest, Nature, 452, 737-740, 2008.
Lilly, D. K.: Models of cloud-topped mixed-layer under a strong inversion, Q. J. Roy. Meteorol. Soc., 94, 292-309, 1968.

Madronich, S., Flocke, S., Zeng, J., Petropavlovskikh, I., and LeeTaylor, J.: Tropospheric Ultraviolet-Visible Model (TUV), http: //cprm.acd.ucar.edu/Models/TUV/, 2011.

Martin, C. L., Fitzjarrald, D., Garstang, M., Oliveira, A., Greco, S., and Browell, E.: Structure and growth of the mixing layer over the Amazonian rain forest, J. Geophys. Res., 93, 1361-1375, 1988.

Ouwersloot, H. G., Vilà-Guerau de Arellano, J., van Heerwaarden, C. C., Ganzeveld, L. N., Krol, M. C., and Lelieveld, J.: On the segregation of chemical species in a clear boundary layer over heterogeneous land surfaces, Atmos. Chem. Phys., 11, 1068110704, doi:10.5194/acp-11-10681-2011, 2011.

Paulot, F., Crounse, J. D., Kjaergaard, H. G., Kroll, J. H., Seinfeld, J. H., and Wennberg, P. O.: Isoprene photooxidation: new insights into the production of acids and organic nitrates, Atmos. Chem. Phys., 9, 1479-1501, doi:10.5194/acp-9-1479-2009, 2009.

Peeters, J., Nguyen, T. L., and Vereecken, L.: $\mathrm{HO}_{\mathrm{x}}$ radical regeneration in the oxidation of isoprene, Phys. Chem. Chem. Phys., 11, 5935-5939, 2009.

Sander, R., Baumgaertner, A., Gromov, S., Harder, H., Jöckel, P., Kerkweg, A., Kubistin, D., Regelin, E., Riede, H., Sandu, A., Taraborrelli, D., Tost, H., and Xie, Z.-Q.: The atmospheric chemistry box model CAABA/MECCA-3.0, Geosci. Model Dev., 4, 373-380, doi:10.5194/gmd-4-373-2011, 2011.

Sinha, V., Williams, J., Crowley, J. N., and Lelieveld, J.: The Comparative Reactivity Method - a new tool to measure total $\mathrm{OH}$ Reactivity in ambient air, Atmos. Chem. Phys., 8, 2213-2227, doi:10.5194/acp-8-2213-2008, 2008.

Sinha, V., Williams, J., Diesch, J. M., Drewnick, F., Martinez, M., Harder, H., Regelin, E., Kubistin, D., Bozem, H., HosaynaliBeygi, Z., Fischer, H., Andrés-Hernández, M. D., Kartal, D., Adame, J. A., and Lelieveld, J.: OH reactivity measurements in a coastal location in Southwestern Spain during DOMINO, Atmos. Chem. Phys. Discuss., 12, 4979-5014, doi:10.5194/acpd12-4979-2012, 2012.

Sörgel, M., Regelin, E., Bozem, H., Diesch, J.-M., Drewnick, F., Fischer, H., Harder, H., Held, A., Hosaynali-Beygi, Z., Martinez, M., and Zetzsch, C.: Quantification of the unknown HONO daytime source and its relation to $\mathrm{NO}_{2}$, Atmos. Chem. Phys., 11, 10433-10447, doi:10.5194/acp-11-10433-2011, 2011.

Stavrakou, T., Peeters, J., and Müller, J.-F.: Improved global modelling of HOx recycling in isoprene oxidation: evaluation against the GABRIEL and INTEX-A aircraft campaign measurements, Atmos. Chem. Phys., 10, 9863-9878, doi:10.5194/acp-10-98632010, 2010.

Stull, R. B.: An introduction to boundary layer meteorology, Kluwer Academic Publishers, 1988.

Tennekes, H. and Driedonks, A. G. M.: Basic entrainment equations for the atmospheric boundary layer, Bound-Lay. Meteorol., 20, 515-531, 1981.

Vilà-Guerau de Arellano, J.: Bridging the gap between atmospheric physics and chemistry in studies of small-scale turbulence, B. Am. Meteorol. Soc., 84, 51-56, 2003.

Vilá-Guerau de Arellano, J., Gioli, B., Miglietta, F., Jonker, H., Baltink, H., Hutjes, R., and Holtslag, A.: Entrainment process of carbon dioxide in the atmospheric boundary layer, J. Geophys. Res-Atmos., 109, 1-15, D18110, 2004. 
Vilà-Guerau de Arellano, J., van den Dries, K., and Pino, D.: On inferring isoprene emission surface flux from atmospheric boundary layer concentration measurements, Atmos. Chem. Phys., 9, 3629-3640, doi:10.5194/acp-9-3629-2009, 2009.

Vilà-Guerau de Arellano, J., Patton, E. G., Karl, T., van den Dries, K., Barth, M. C., and Orlando, J. J.: The role of boundary layer dynamics on the diurnal evolution of isoprene and the hydroxyl radical over tropical forests, J. Geophys. Res.-Atmos., 116, D07304, doi:10.1029/2010JD014857 2011.

Vinuesa, J. F. and Vilá-Guerau de Arellano, J.: Fluxes and (co-)variances of reacting scalars in the convective boundary layer, Tellus B, 55, 935-949, 2003.

Wiegand, A. N. and Bofinger, N. D.: Review of empirical methods for the calculation of the diurnal $\mathrm{NO}_{2}$ photolysis rate coefficient, Atmos. Environ., 34, 99-108, 2000.

Williams, J., Crowley, J., Fischer, H., Harder, H., Martinez, M., Petäjä, T., Rinne, J., Bäck, J., Boy, M., Dal Maso, M., Hakala, J., Kajos, M., Keronen, P., Rantala, P., Aalto, J., Aaltonen, H., Paatero, J., Vesala, T., Hakola, H., Levula, J., Pohja, T., Herrmann, F., Auld, J., Mesarchaki, E., Song, W., Yassaa, N., Nölscher, A., Johnson, A. M., Custer, T., Sinha, V., Thieser, J., Pouvesle, N., Taraborrelli, D., Tang, M. J., Bozem, H., Hosaynali-Beygi, Z., Axinte, R., Oswald, R., Novelli, A., Kubistin, D., Hens, K., Javed, U., Trawny, K., Breitenberger, C., Hidalgo, P. J., Ebben, C. J., Geiger, F. M., Corrigan, A. L., Russell, L. M., Ouwersloot, H. G., Vilà-Guerau de Arellano, J., Ganzeveld, L., Vogel, A., Beck, M., Bayerle, A., Kampf, C. J., Bertelmann, M., Köllner, F., Hoffmann, T., Valverde, J., González, D., Riekkola, M.-L., Kulmala, M., and Lelieveld, J.: The summertime Boreal forest field measurement intensive (HUMPPA-COPEC-2010): an overview of meteorological and chemical influences, Atmos. Chem. Phys., 11, 10599-10618, doi:10.5194/acp-11-10599-2011, 2011.
Yokelson, R. J., Karl, T., Artaxo, P., Blake, D. R., Christian, T. J., Griffith, D. W. T., Guenther, A., and Hao, W. M.: The Tropical Forest and Fire Emissions Experiment: overview and airborne fire emission factor measurements, Atmos. Chem. Phys., 7, 5175-5196, doi:10.5194/acp-7-5175-2007, 2007. 